\title{
PENDOKUMENTASIAN KEPERAWATAN DI RUMAH SAKIT
}

\author{
Fanisa Nur Siregar \\ fanisanursiregar09@gmail.com
}

\section{LATAR BELAKANG}

Pelayanan keperawatan merupakan bagian dari sistem pelayanan kesehatan yang dapat menentukan mutu pelayanan kesehatan di rumah sakit. Seorang perawat mempunyai peranan penting dalam memberikan asuhan keperawatan. Asuhan keperawatan merupakan proses keperawatan yang diberikan perawat kepada kliennya. Adapun proses keperawatan berupa pengkajian, diagnose keperawatan, intervensi keperawatan, implementasi keperawatan dan ealuasi, serta dokumentasi keperawatan. Dokumentasi dalam keperawatan memegang peranan penting terhadap segala macam tuntutan masyarakat yang semakin kritis dan mempengaruhi kesadaran masyarakat akan hak-haknya dari suatu unit kesehatan. Pendokumentasian yang tidak dilakukan dengan lengkap dapat menurunkan mutu pelayanan keperawatan karena tidak dapat mengidentifikasi sejauh mana tingkat keberhasilan asuhan keperawatan yang telah diberikan. Kegiatan Dokumentasi keperawatan merupakan suatu aspek penting yang perlu ditingkatkan oleh perawat di setiap pelayanan kesehatan. Pendokumentasian sangat diperlukan bagi rumah sakit dalam meningkatkan standar akreditasnya.

Dokumentasi merupakan hal yang sangat penting harus dilakukan oleh seorang perawat dalam memberikan asuhannya kepada klien agar tetap mencatat setiap tindakan yang dilakukan. Dokumentasi asuhan keperawatan ialah bagian integral dari asuhan keperawatan yang dilaksanakan sesuai dengan standar, dengan demikian uraian serta keahlian dalam mempraktikkan standar dengan baik sebagai sesuatu perihal yang mutlak untuk tiap tenaga keperawatan supaya mampu untuk membuat dokumentasi keperawatan secara baik serta benar. Dokumentasi yang efektif harus dapat menjamin kesinambungan pelayanan, menghemat waktu, dan meminimalisasi resiko kesalahan yang terjadi saat memberikan asuhan keperawatan kepada klien.

Dokumentasi dalam keperawatan merupakan sebuah aspek legal yang melindungi perawat dalam memberikan pelayanan kesehatan kepada klien. Tetapi masih sering di temukan 
dokumentasi keperawatan yang masih belum lengkap di rumah sakit. Dokumentasi proses asuhan keperawatan yang baik dan berkualitas haruslah akurat, lengkap dan sesuai standar yang telah ditentukan. Apabila semua tindakan keperawatan tidak didokumentasikan dengan akurat dan lengkap maka akan sulit untuk membuktikan bahwa tindakan keperawatan yang telah dilakukan adalah benar.

Dokumentasi keperawatan menjadi salah satu fungsi yang paling penting dari perawat sejak zaman Florence Nightingale, sistem pelayanan kesehatan mengharuskan adanya pendokumentasian karena dapat menjamin kelangsungan perawatan, dapat berfungsi sebagai bukti hukum dari proses perawatan dan mendukung evaluasi kualitas perawatan pasien, perawat yang kurang patuh dalam pendokumentasi asuhan keperawatan akan berakibat pada rendahnya mutu kelengkapan dokumentasi asuhan keperawatan. Saat ini, dokumentasi tetap berorientasi pada proses, menekankan pada tugas yang dilakukan oleh pemberi perawatan. Kelengkapan pendokumentasian keperawatan diduga karena ada beberapa faktor, antara lain yaitu karena kesibukan kerja perawat, pengalaman kerja (lama kerja) yang dimiliki perawat, kedisiplinan maupun tingkatan pendidikan yang dimiliki perawat ataupun persepsi perawat terhadap pentingnya penulisan dokumentasi keperawatan.

\section{METODE}

Metode dalam pembuatan jurnal ini dilakukan dengan cara mengumpulkan data dari buku, jurnal, dan thesis dan e-book, kemudian melakukan analisis secara mendalam terkait topik yang dibahas, serta bersifat subjektif yaitu proses penulisan yang lebih fokus pada landasan teori. Dan melakukan analisis buku dan e-jurnal yang relevan dan berfokus pada Dokumentasi Keperawatan Di Rumah Sakit. Dengan menggunakan sumber dengan terbitan paling tua tahun 2012. Adapun referensi akan dicantumkan dalam penulisan ini dengan jelas terdapat pada daftar pustaka pada bagian akhir penulisan.

\section{HASIL}

Dokumentasi keperawatan merupakan aspek penting yang perlu ditingkatkan. Dokumentasi keperawatan menjadi salah satu fungsi yang paling penting dari perawat sejak zaman Florence Nightingale, sistem pelayanan kesehatan mengharuskan adanya pendokumentasian karena dapat menjamin kelangsungan perawatan, dapat berfungsi sebagai 
bukti hukum dari proses perawatan dan mendukung evaluasi kualitas perawatan pasien, perawat yang kurang patuh dalam pendokumentasi asuhan keperawatan akan berakibat pada rendahnya mutu kelengkapan dokumentasi asuhan keperawatan

Dokumentasi ialah sesuatu data lengkap meliputi status kesehatan klien, kebutuhan kliena, aktivitas asuhan keperawatan, dan reaksi klien terhadap asuhan yang diterimanya. Menurut Fishback, dokumentasi adalah suatu dokumen yang berisi data lengkap, nyata dan tercatat, bukan hanya tingkat kesakitan pasien, tetapi juga jenis dan kualitas pelayanan kesehatan yang diberikan.

Pengertian dokumentasi keperawatan menurut Kozier (2004) adalah laporan baik secara lisan, tertulis, maupun melalui komputer untuk menyampaikan informasi kepada orang lain. Tujuan dokumentasi keperawatan adalah sebagai sarana komunikasi antara perawat dan klien, sebagai tanggung jawab dan tanggung gugat, sebagai informasi statistik bagi rumah sakit, sebagai sarana pendidikan, sebagai sumber data penilitian. Kelengkapan pendokumentasian keperawatan diduga karena ada beberapa faktor, antara lain yaitu karena kesibukan kerja perawat, pengalaman kerja (lama kerja) yang dimiliki perawat, kedisiplinan maupun tingkatan pendidikan yang dimiliki perawat ataupun persepsi perawat terhadap pentingnya penulisan dokumentasi keperawatan. Dokumentasi dalam keperawatan memegang peranan penting terhadap segala macam tuntutan masyarakat yang semakin kritis dan mempengaruhi kesadaran masyarakat akan hak-haknya dari suatu unit kesehatan. Pendokumentasian yang tidak dilakukan dengan lengkap dapat menurunkan mutu pelayanan keperawatan karena tidak dapat mengidentifikasi sejauh mana tingkat keberhasilan asuhan keperawatan yang telah diberikan.

\section{PEMBAHASAN}

\section{Pengertian}

Menurut Fishback, dokumentasi adalah suatu dokumen yang berisi data lengkap, nyata dan tercatat, bukan hanya tingkat kesakitan pasien, tetapi juga jenis dan kualitas pelayanan kesehatan yang diberikan. Pengertian Dokumentasi Keperawatan menurut Kozier (2004) adalah laporan baik secara lisan, tertulis, maupun melalui komputer untuk menyampaikan informasi kepada orang lain. 
Jadi Dokumentasi ialah sesuatu data lengkap meliputi status kesehatan klien, kebutuhan kliena, aktivitas asuhan keperawatan, dan reaksi klien terhadap asuhan yang diterimanya. Dengan demikian, dokumentasi keperawatan memiliki posisi yang besar dari catatan klinis klien yang menginformasikan aspek tertentu ataupun suasana yang terjalin selama masa asuhan dilaksanakan

\section{Tujuan Dokumentasi Keperawatan}

Dokumentasi dalam keperawatan tentu memiliki tujuan. Adapun tujuannya ialah :

- Sebagai sarana komunikasi antara perawat dan klien

- Sebagai tanggung jawab dan tanggung gugat

- Sebagai informasi statistik bagi rumah sakit

- Sebagai sarana pendidikan

- Sebagai sumber data penilitian

- Sebagai jaminan kualitas pelayanan kesehatan yang bermutu

- Sebagai sumber data perencanaan asuhan keperawatan berkelanjutan

\section{Prinsip-prinsip Pendokumentasian}

Hal- hal pokok dalam prinsip-prinsip pendokumentasian adalah :

a) Dokumentasi harus dilakukan segera setelah melakukan pengkajian pertama, demikian juga di setiap langkah kegiatan keperawatan yang akan dilaksanakan.

b) Bila memungkinkan, catat setiap respon pasien/keluarganya yang diberikan terutama tentang informasi/data yang penting tentang keadaannya.

c) Pastikan kebenaran setiap data pasien yang akan dicatat.

d) Data pasien harus objektif dan bukan merupakan persepsi perawat, dalam hal ini perawat mencatat apa yang dilihatnya dari respon pasien pada saat melakuka tindakan merawat pasien mulai dari pengkajian sampai evaluasi.

e) Dokumentasikan dengan baik apabila terjadi hal-hal sebagai berikut : adanya perubahan kondisi atau munculnya masalah baru, respon pasien terhadap bimbingan perawat. 
f) Harus menghindari dokumentasi yang baku, sebab sifat individu/pasien adalah unik dan setiap pasien mempunyai masalah yang berbeda.

g) Hindari penggunaan penulisan yang tidak jelas dari setiap catatan yang telah dicatat, harus disepakati atas kebijaksanaan institusi setempat.

h) Data harus ditulis secara resmi dengan menggunakan tinta dan jangan menggunakan pensil agar tidak mudah dihapus. Ingat saat merubah atau menutupi kesalahan apabila terjadi salah tulis, coret dan diganti dengan yang benar kemudian ditanda tangani.

i) Untuk setiap kegiatan dokumentasi, jangan lupa cantumkan waktu, tanda tangan dan nama jelas perawata yang menulis.

j) Wajib membaca setiap tulisan dari anggota kesehatan lain sebelum menulis data terakhir.

k) Dokumentasi harus dibuat dengan tepat, jelas dan lengkap.

\section{Manfaat dokumentasi keperawatan}

Dokumentasi keperawatan mempunyai makna yang penting dilihat dari berbagai aspek sebagai berikut :

\section{a. Hukum}

Semua catatan informasi tentang klien merupakan dokumentasi resmi dan bernilai hukum. Bila terjadi suatu masalah (misconduct) yang berhubungan dengan profesi keperawatan, dimana perawat sebagai pemberi jasa dan klien sebagai pengguna jasa, maka dokumentasi dapat dipergunakan sewaktu-waktu. Dokumentasi tersebut dapat dipergunakan sebagai barang bukti di pengadilan. Oleh karena itu data-dat harus diidentifikasi secara lengkap , jelas, objektif, dan ditanda tangani oleh tenaga kesehatan (perawat), tanggal, dan perlu dihindari adanya penulisan yang dapat menimbulkan interpretasi yang salah.

b. Kualitas pelayanan

Pendokumentasian data klien yang lengkap dan akurat, akan memberi kemudahan bagi perawat dalam menyelesaikan masalah klien. Dan untuk mengetahui sejauh mana masalah klien dapat teratasi dan seberapa jauh masalah dapat diidentifikasi dan dimonitor melalui dokumentasi yang akurat. Hal ini akan membantu meningkatkan kualitas (mutu) pelayanan keperawatan. 


\section{c. Komunikasi}

Dokumentasi keadaan klien merupakan alat "perekam” terhadap masalah yang berkaitan dengan klien. Perawat atau profesi kesehatan lain dapat melihat dokumentasi yang ada dan sebagai alat komunikasi yang dijadikan pedoman dalam memberikan asuhan keperawatan.

\section{d. Keuangan}

Dokumentasi dapat bernilai keuangan. Semua asuhan keperawatan yang belum, sedang dan telah diberikan didokumentasikan dengan lengkap dan dapat dipergunakan sebagai acuan dalam biaya untuk klien.

e. Pendidikan

Dokumentasi mempunyai nilai pendidikan, karena isinya menyangkut kronologis dari kegiatan asuhan keperawatan yang dapat dipergunakan sebagai bahan pembelajaran bagi peserta didik atau profesi keperawatan.

\section{f. Akreditasi}

Melalui dokumentasi keperawatan akan dapat dilihat sejauh mana peran dan fungsi perawat dalam memberikan asuhan keperawatan kepada klien. Dengan demikian dapat diambil kesimpulan mengenai tingkat keberhasilan pemberian asuhan keperawatan yang diberikan guna pembinaan dan pengembangan lebih lanjut. Hal ini selain bermanfaat bagi peningkatan kualitas pelayanan, juga bagi individu perawat dalam mencapai tingkat kepangkatan yang lebih tinggi (Nursalam, 2008).

\section{Jenis dokumentasi}

\section{a. Format SOR (Source Oriented Record)}

Format SOR merupakan format yang dipakai untuk mencatat perkembangan klien dari hari ke hari yang berbentuk seperti cerita. Catatan ini merupakan informasi yang bersumber dari setiap tenaga kesehatan yang memberikan pelayanan

b. Format POR (Proplem Oriented Record) 
Merupakan format yang berorientasi pada masalah yang diidentifikasikan oleh semua anggota tim keperawatan. Jenis pencatatan ini terdiri dari 4 komponen yaitu data dasar, daftar masalah, rencana keperawatan dan catatan perkembangan. Data dasar berisi informasi yang didapat dari pengkajian berupa subyejtif dan obyektif. Daftar masalah berisi tentang masalah klien yang telah teridentifikasi dari data dasar. Rencana keperawatan berisi rencana tindakan yang akan diberikan dan tujuan. Catatan perkembangan berisi hasil evaluasi, tingkat pencapaian tujuan, dan perencanaan pulang. Sehingga pencatatan ini dikenal dengan pencatatan soapier.

\section{c. Format POR (Progress Oriented Record)}

Format ini mempunyai 3 jenis catatan perkembangan yaitu catatan perawat, flowsheet atau lembar alur, dan catatan pemulangan atau ringkasan rujukan. Catatan perawat meliputi berbagai informasi tentang pengkajian, tindakan keperawatan baik bersifat mandiri atau kolaboratif. flowsheet atau lembar alur berisi catatan hasil observasi termasuk data klinik klien tentang tanda vital, berat badan, balance cairan dan pemberian obat. Catatan perkembangan dan ringkasan rujukan berisi informasi yang di perlukan sebelum klien pulang.

\section{Faktor yang mempengaruhi pendokumentasian keperawatan}
a. Sikap

Sikap berhubungan sebab akibat dengan perilaku pendokumentasian asuhan keperawatan. Menurut Green dalam Notoatmodjo (2010) mengatakan bahwa sikap menentukan perilaku seseorang. Sikap yang positif diharapkan menjadi dorongan yang kuat dalam usaha melakukan pendokumentasian asuhan keperawatan. Perawat yang memiliki sikap positif berpeluang 8 kali untuk melakukan pendokumentasian asuhan keperawatan Baik dan benar daripada perawat yang memiliki sikap negatif.

\section{b. Pengetahuan perawat}

Perawat yang memiliki pengetahuan yang baik pasti akanmelakukan pendokumentasien dengan baik juga. Karena tingkat pengetahuan sanagat mempengaruhi pendokumentasian keperawatan. 


\section{PENUTUP}

Dokumentasi adalah hal yang sangat penting yang dilakukan oleh seorang perawat untuk tetap mencatat setiap tindakan yang dilakukan. Dokumentasi juga merupakan salah satu mekanisme yang digunakan untuk mengevaluasi perawatan yang diberikan. Dokumentasi keperawatan merupakan aspek penting yang perlu ditingkatkan. Menurut Nursalam (2008) hakikat dokumentasi asuhan keperawatan adalah terciptanya kegiatan-kegiatan keperawatan yang menjamin tumbuhnya pandangan, sikap, cara berpikir, dan bertindak profesional pada setiap perawat. Pendekatan yang sistematis dan logis dengan landasan ilmiah yang benar, serta melalui dokumentasi proses keperawatan, semua kegiatan dalam proses keperawatan dapat ditampilkan kembali sehingga dapat diteliti ulang untuk dikembangkan atau diperbaiki

\section{DAFTAR PUSTAKA}

Budiono. (2016). Konsep Dasar Keperawatan. Jakarta : Bumi Medika.

Kasim, M., \& Abdurrouf, M. (2016). PENINGKATAN KUALITAS PELAYANAN DAN PENDOKUMENTASIAN ASUHAN KEPERAWATAN DENGAN METODE TIM. NurseLine Journal Vol. 1 No. 1, 62-72.

Kusnadi, E. (2017). Analisis Kelengkapan Dokumentasi Keperawatan di Ruang Rawat Inap Non Intensive Rumah Sakit X. Jurnal Bidang Ilmu Kesehatan Vol. 9, No. 1, 553-562.

Rezky. (2018). Gambaran Faktor Yang Mempengaruhi Pelaksanaan Asuhan Keperawatan Individu Di Puskesmas Kota Makassar. Skripsi-Universitas Hasanuddin Makassar. Makassar: Tidak Dipublikasikan.

Salmawati. (2013). Faktor Yang Berhubungan Dengan Pelaksanaan Dokumentasi Asuhan Keperawatan Di Ruang Perawatan Rsud Labuang Baji Makassar. Skripsi-Uin Alauddin Makassar. Makassar: Tidak Dipublikasikan.

Simamora, R. (2009). Dokumentasi Proses Keperawatan.

Simamora, R. H., Purba, J. M., Bukit, E. K., \& Nurbaiti, N. (2019). Penguatan Peran Perawat Dalam Pelaksanaan Asuhan Keperawatan Melalui Pelatihan Layanan Prima. JPPM (Jurnal Pengabdian Dan Pemberdayaan Masyarakat), 3(1), 25-31. 
Supratti, \& Ashriady. (2016). PENDOKUMENTASIAN STANDAR ASUHAN KEPERAWATAN DI RUMAH SAKIT UMUM DAERAH MAMUJU, INDONESIA. Jurnal Kesehatan MANARANG Volume 2, Nomor 1, 44-51.

Susiana, E. (2013).Faktor Yang Berhubungan Dengan Mutu Pendokumentasian Asuhan Keperawatan Di Rsud Dr. Soetomo Surabaya. Skripsi- Universitas Airlangga Surabaya. Surabaya: Tidak Dipublikasikan.

Wulandini, P., \& dkk. (2016). FAKTOR-FAKTOR YANG BERHUBUNGAN DENGAN PENDOKUMENTASIAN ASUHAN KEPERAWATAN DI RUMAH SAKIT JIWA. NERS JURNAL KEPERAWATAN, Volume 12 No.2, 131-142.

Yanti, R. I., \& Warsito, B. E. (2013). HUBUNGAN KARAKTERISTIK PERAWAT, MOTIVASI, DAN SUPERVISI DENGAN KUALITAS DOKUMENTASI PROSES ASUHAN KEPERAWATAN. Jurnal Managemen Keperawatan . Volume 1, No. 2, 107114.

Yeni, F. (2014). Pengaruh Pelatihan Proses Keperawatan terhadap Dokumentasi Asuhan Keperawatan di Puskesmas Kabupaten Agam Propinsi Sumatera Barat. NERS JURNAL KEPERAWATAN Volume 10, No 1, 21-27. 